\title{
Implementasi Bina Pribadi Islam (BPI) dalam Membina Akhlak Peserta Didik di Sekolah Dasar Inspiratif Al-Ilham Kota Banjar
}

\author{
Fani Fadliyani \\ Institut Agama Islam Darussalam (IAID), Ciamis-Jawa Barat \\ Email: yani.fadlilyanibjr@gmail.com \\ Yosep Farhan Dafik Sahal \\ Institut Agama Islam Darussalam (IAID), Ciamis-Jawa Barat \\ Muhamad Aris Munawar \\ Institut Agama Islam Darussalam (IAID), Ciamis-Jawa Barat
}

\begin{abstract}
This study aims: (1) to determine the morals of students in SD Inspiratif Al-Ilham, Banjar City. (2) to determine the implementation of Islamic Personal Development (BPI) in building the morals of students at SD Inspiratif Al-Ilham, Banjar City. (3) to find out the results of the Islamic Personal Development (BPI) in building the morals of students at SD Inspiratif Al-Ilham, Banjar City. The purpose of this study was to determine the morals of students, the implementation of Islamic Personal Development and to find out the results of Islamic Personal Development in fostering the morals of students at SD Inspiratif Al-Ilham, Banjar City. This study used a qualitative research method with a case study approach. This study used data collection techniques using interviews, observation, and documentation study. The data used are primary data obtained directly from respondents regarding the implementation of Islamic Personal Development. Meanwhile, secondary data in the form of theories and other supporting data were obtained from literature and school archives documentation. All of these data are materials to describe the implementation of Islamic Personal Development (BPI) at SD Inspiratif Al-Ilham, Banjar City. The results of this study indicate that: (1) The morals of the students at SD Inspiratif Al-Ilham, Banjar City are good enough. (2) Implementation of Islamic Personal Development in fostering the morals of students at Inspiratif Al-Ilham Elementary School, Banjar City, namely through coaching which includes guidance by exemplary, guidance with habituation and guidance with advice (3) The results of the Islamic Personal Development (BPI) in fostering the morals of students at the Inspiratif Al-Ilham Elementary School, Banjar City are quite good, where students have been able to show behavior according to the existing indicators, including being able to carry out congregational prayers and prayers. sunnah dhuha and qiyamullail, reciting dhikr after every prayer and so on.
\end{abstract}


Keywords: Islamic Habitualism, Students Character

\section{PENDAHULUAN}

Pendidikan memiliki kedudukan yang sangat penting dalam kehidupan manusia, guna mencapai tujuan yang ingin dicapai. Tujuan tersebut yaitu dirumuskan dalam UU RI No 20 Tahun 2003 Bab II pasal 3. Dalam ketetapan Undang-Undang tentang sistem pendidikan nasional, dirumuskan bahwa tujuan dan fungsi pendidikan adalah membentuk manusia Indonesia seutuhnya yang kata kuncinya adalah beriman dan bertaqwa berakhlak mulia, sehat, berilmu, cakap, kreatif, mandiri, dan menjadi warga negara yang demokratis serta bertanggung jawab.

Jika dilihat lebih dalam dimensi "keutuhan manusia" dalam UU tersebut terdiri dari dua bagian yang saling terkait. Dimensi tersebut yaitu dimensi religius dan sosial. Religius pada ranah ketaqwaan serta keimanan dan sosial pada bidang kecakapan, kemandirian, kewarganegaraan yang demokratis serta bertanggung jawab. Maka dalam upaya pencapaian manusia yang utuh memerlukan sistem pendidikan yang benar (Suryadarma, 2015)

Pendidikan adalah bekal bagi perkembangan hidup manusia untuk berusaha belajar dari yang tidak dimengerti menjadi mengerti, dari belum mengenal menjadi kenal, dan menjadikan manusia lebih berarti dalam segala aspek kehidupannya, maka dari itu pendidikan memerankan peran yang sangat penting dalam membentuk suatu kualitas bangsa (Fathurrohman, 2016)

Proses kegiatan secara formal diwujudkan dalam kegiatan pembelajaran di sekolah. Untuk mencapai tujuan tertentu, pembelajaran dapat dilakukan melalui kegiatan belajar yang berkualitas. Hasil belajar yang baik dicapai melalui interaksi dan berbagai faktor yang saling mendukung satu sama lain. Pendidikan sebagai usaha dan kegiatan manusia dewasa terhadap manusia yang belum dewasa, bertujuan untuk menggali potensi-potensi terbaru dan dapat dikembangkan (Shawmi, 2016, p. 122)

Agama Islam telah meletakan solusi dan metode untuk menumbuhkan kepribadian peserta didik dari sisi kaidah, akhlak, fisik, akal, mental dan sosialnya. Jika para pendidik dapat menerapkanya dalam membentuk generasi-generasi penerus dan mendidik masyarakat dan bangsa, pastilah satu bangsa akan tergantikan oleh bangsa yang baik, satu generasi akan diteruskan oleh generasi yang baik juga. Keteladanan dalam pendidikan adalah cara yang paling efektif dan berhasil dalam mempersiapkan peserta didik dari segi akhlak, dan pembentukkan mental. (Nasution, 2019, p. 154). Dalam hal ini karena pendidik merupakan panutan atau idola dalam pandangan peserta didik dan contoh yang baik di mata mereka. Peserta didik akan mengikuti tingkah laku pendidiknya, meniru akhlaknya, baik disadari maupun tidak (Nasution, 2019, p. 91) 


\section{BESTARI}

Vol. 17, No. 2, 2020

p-ISSN 1907-1337; e-ISSN 2807-6532

Keteladanan seorang pendidik menjadi suatu faktor yang menjadi pengaruh untuk baik dan buruknya akhlak seorang peserta didik. Apabila seorang pendidik itu sosok yang jujur dan terpercaya, maka peserta didik akan tumbuh dalam kejujuran dan sikap amanah. Namun juga sebaliknya, apabila seorang pendidik adalah orang yang pendusta dan khianat, maka peserta didik juga akan tumbuh dengan kebiasaan dusta dan tidak bisa dipercaya.

Selain itu metode pendidikan yang efektif dalam membentuk keimanan peserta didik, akhlak, mental, dan sosialnya, adalah metode mendidik dengan nasihat. Hal ini dikarenakan, nasihat memiliki pengaruh yang besar untuk membuat peserta didik mengerti tentang hakikat sesuatu dan memberinya kesadaran tentang prinsip-prinsip Islam (Nasution, 2019, p. 93)

Salah satu usaha dalam membentuk akhlak peserta didik di lingkungan SD Inspiratif Al Ilham yaitu dengan adanya Bina Pribadi Islam (BPI). Bina Pribadi Islam ini merupakan program yang dirancang oleh yayasan Islam terpadu di seluruh Indonesia. Bina Pribadi Islam adalah sebuah proses pendampingan untuk peningkatan hubungan antara anak dan orang tua, teman sebaya dan guru yang multidimensional guna membantu anak menghadapi tantangan dan masalah dalam kesehariannya. Pada dasarnya inti dari Bina Pribadi Islam yaitu suatu pembinaan Islami.

Tujuan dilaksanakan Bina Pribadi Islam yaitu untuk meningkatkan kecerdasan spiritual pada peserta didik agar tidak terjerumus dalam penyimpangan terhadap sikap keberagamaan dan sosial, mendampingi dan mengarahkan peserta didik dalam mengkaji dan mengaplikasikan nilai-nilai keIslaman dalam dirinya sehingga memiliki budi pekerti atau akhlak mulia yang ditunjang dengan penguasaan ilmu dengan baik yang kemudian mampu mengamalkan ilmunya dengan tetap dilandasi oleh iman yang benar.

Akhlak adalah pondasi yang utama dalam pembentukan pribadi manusia seutuhnya. Pendidikan yang mengarah pada terbentuknya pribadi yang berakhlak, dilakukan dengan teratur dan terarah agar peserta didik dapat mengembangkan dan mempraktekannya dalam kehidupan sehari-hari (Sylviyanah, 2012, p. 192)

Dalam dunia pendidikan, khususnya di sekolah, akhlak pada peserta didik harus ditanamkan, karena baik dan buruknya akhlak peserta didik bangsa ini, sangat ada kaitanya dengan baik dan buruknya penanaman akhlak pada peserta didik saat masih di bangku sekolah. Oleh karena itu, sekolah adalah tempat utama untuk membentuk baik manusia yang berakhlak dan berakal.

Berdasarkan latar belakang yang telah dijabarkan oleh penulis tentang pentingnya pendidikan akhlak dan penanaman akhlak peserta didik di usia sekolah dasar, maka penulis tertarik untuk meneliti sejauh mana implementasi pembinaan akhlak di sekolah dasar (SD) Inspiratif 
Al-Ilham Kota Banjar, dalam pembinaan akhlak peserta didik melalui suatu program yaitu Bina Pribadi Islam. Oleh karena itu peneliti menempatkan penelitian ini di SD Inspiratif Al-Ilham Kota Banjar yang menurut peneliti sekolah ini memiliki nilai tambah atau nilai lebih dari sekolah-sekolah lain. Di sekolah ini juga memiliki program, yang mana hal ini telah di laksanakan sejak pertama kali berdirinya SD Inspiratif AlIlham, yaitu menjalankan program pembinaan akhlak peserta didik atau di sebut dengan Bina Pribadi Islam.

Adapun metode penelitian yang digunakan dalam penelitian ini adalah penelitian kualitatif lapangan, dengan pendekatan studi kasus. Penelitian kualitatif adalah proses pemecahan suatu masalah yang berhubungan dengan manusia dengan bertujuan untuk memahami fenomena yang terjadi, dengan latar belakang sosial maupun kultural. Penelitian ini dilakukan dengan tidak menganalisa angka dan melaporkan deskripsi hasil penelitian secara detail (Pertiwi \& Weganofa, 2015: 19).

Pada pendekatan kualitatif arah dan fokus suatu penelitian adalah membangun teori dari data atau fakta, mengembangkan sintesa interaksi dan teori-teori yang dibangun dari fakta-fakta mendasar (grounded) mengembangkan pengertian, dan sebagainya yang berarti tiap langkah mengutamakan proses apa adanya dan tanpa dibatasi norma-norma, rumus, dan yang lainnya (Musianto, 2002: 128).

Tujuan utama penelitian kualitatif yaitu untuk menangkap arti (meaning/ understanding) yang terdalam atas suatu kejadian, gejala, fakta atau masalah tertentu dan bukan untuk mempelajari atau membuktikan adanya hubungan sebab akibat dari suatu masalah atau peristiwa (Raco, 2010: 106).

Dalam hal ini penulis bermaksud untuk meneliti Implementasi Bina Pribadi Islam (BPI) Dalam Membina Akhlak Peserta Didik di SD Inspiratif Al-Ilham Kota Banjar. Penulis akan melakukan analisis data dengan menggali informasi yang mendalam dengan objek penelitian.

\section{KAJIAN TEORI}

\section{Konsep Pembinaan}

Pembinaan berasal dari kata arab "bana" yang berarti membina, membangun, mendirikan. Secara istilah pembinaan merupakan proses, perbuatan, cara membina, usaha, tindakan dan kegiatan yang dilakukan secara berdaya guna dan berhasil guna untuk memperoleh hasil yang lebih baik (Binaria, 2017)

Menurut Langeveld, pembinaan adalah setiap usaha, pengaruh, perlindungan dan bantuan yang diberikan kepada anak tertuju kepada kedewasaan anak itu, atau lebih tepat membantu agar anak cukup cakap melaksanakan tugas hidupnya sendiri. Dari pendapat di atas dapat disimpulkan bahwa pembinaan adalah bimbingan, pelatihan, usaha yang dilakukan oleh pendidik demi terbentuknya kedewasaan dan kecakapan 


\section{BESTARI}

Vol. 17, No. 2, 2020

p-ISSN 1907-1337; e-ISSN 2807-6532

pada anak didik itu sendiri agar mampu menjalankan tugas hidupnya (Halimah, 2017, p. 11)

Djuju Sudjana dalam Selly Sylviyanah (2012: 195) menyebutkan bahwa fungsi pembinaan, baik pengawasan ataupun supervisi, dapat dilakukan dengan melakukan pendekatan secara langsung dan tidak langsung. Pendekatan langsung terjadi apabila pihak pembina melakukan pembinaan melalui tatap muka dengan pihak yang dibina atau dengan pelaksanaan program.

\section{2. $\quad$ Bina Pribadi Islam (BPI)}

a. Pengertian Bina Pribadi Islam

Bina Pribadi Islam merupakan kegiatan pembinaan kearah terbentuknya akhlak dan kepribadian Islam yang dicerminkan dalam pola fikir, pola sikap, dan pola prilaku sehari-hari. Pembinaan akhlak ini mengarah kepada upaya pembentukan perilaku santun, bersih, amanah, peduli dan bertanggung jawab (Nurwahid, 2010: 602).

Bina Pribadi Islam adalah program yang dirancang oleh yayasan Islam terpadu diseluruh Indonesia. Bina Pribadi Islam ini merupakan program pendalaman pendidikan Islam ditingkat sekolah dasar Islam terpadu hingga sekolah menengah yang berada dibawah naungan Jaringan Sekolah Islam Terpadu Indonesia dalam rangka menguatkan pelaksanaan pembinaan peserta didik dalam membentuk peserta didik yang barakhlak \& berkakter islami (Aisah, 2019, p. 13)

Program Bina Pribadi Islam juga merupakan program unggulan yang ada di SD Inspiratif Al-Ilham Kota Banjar. Program ini masuk ke dalam kurikulum di SD Inspiratif Al-Ilham Kota Banjar dalam proses Kegiatan Belajar Mengajar (KBM). Kegiatan ini berfokus pada program pembinaan kepribadian Islam melalui kegiatan pembiasaan yang mengacu pada pendalaman pendidikan agama Islam (Aminah, 2017, p. 26)

b. Ruang Lingkup Bina Pribadi Islam

Ruang lingkup Kegiatan Bina Pribadi Islam meliputi (1) Pembinaan berkala dengan menggunakan sarana-sarana tarbiyah sesuai dengan panduan dakwah sekolah. (2) Penumbuhan remaja pelajar pendukung dakwah. (3) Penumbuhan kapasitas kepribadian remaja pelajar muslim. c. Landasan Bina Pribadi Islam

Landasan konsepsional bina pribadi Islam adalah ayat al-Qur'an, “"Hendaklah kamu menjadi orang-orang rabbani, karena kamu selalu mengajarkan Al Kitab dan disebabkan kamu tetap mempelajarinya (Ali Imran: 79).

"Sebagaimana (Kami telah menyempurnakan nikmat Kami kepadamu) Kami telah mengutus kepadamu Rasul di antara kamu yang membacakan ayat-ayat Kami kepada kamu dan mensucikan kamu dan mengajarkan kepadamu Al-Kitab dan Al-Hikmah (As Sunnah), serta 
mengajarkan kepada kamu apa yang belum kamu ketahui (Al Baqarah: 151).

1) Landasan Konstitusional Bina Pribadi Islam

a) Undang-Undang Nomor 20 tahun 2003 tentang Sistem Pendidikan Nasional, Pasal 3, tujuan Pendidikan Nasional adalah "mengembangkan potensi peserta didik agar menjadi manusia yang beriman dan bertakwa kepada Tuhan Yang Maha Esa, berakhlak mulia, sehat, berilmu, cakap, kreatif, mandiri, dan menjadi warga negara yang demokratis serta bertanggung jawab"

b) PP No. 55 tahun 2007 tentang Pendidikan Agama dan Pendidikan Keagamaan, Bab II pasal 2 ayat (1) yakni; "untuk membentuk manusia Indonesia yang beriman dan bertakwa kepada Tuhan Yang Maha Esa serta berakhlak mulia dan mampu menjaga kedamaian dan kerukunan hubungan inter dan antar umat beragama”.

c) Landasan Operasional Bina Pribadi Islam

Amanat Munas III JSIT Indonesia Palembang Tahun 2013 dan Program Kerja Dept PAI, Hisbah dan Tarbiyah Tahun 2013 - 2017 tentang penyusunan Panduan Pelaksanaan Bina Pribadi Islami di Sekolah Islam Terpadu.

d. Karakteristik kurikulum Bina Pribadi Islam

1. Komprehensif (menyeluruh), mencakup berbagai aspek ajaran Islam, dan berbagai bidang studi yang berguna bagi kehidupan, baik syar'i maupun umum.

2. Takamul (sinergis), tarabuth (saling mengikat) dan tasalsul (saling terkait) antara tema yang satu dengan yang lain dan antara ilmu satu dengan ilmu lainnya serta antara bagian satu dengan bagian lainnya.

3. Wasathiyah (moderat) dalam menyuguhkan pemahaman Islam, tidak terjebak kepada ifrath (berlebihan, ekstrem kanan) atau tafrith (kurang, ekstrem kiri).

4. Paduan antara ashalah (orisinalitas) dan mu'asharah (kontemporer).

5. Mahalliyah (lokal), iqlimiyah (regional, kawasan), dan 'alamiyah (internasional) dengan tidak menjadikan pertimbangan lokal atau regional bertabrakan dengan pertimbangan internasional, begitu juga sebaliknya.

6. Murunah (fleksibel) dalam cara menyuguhkan, disesuaikan dengan tingkat perbedaan personal, keragaman lokal, regional, wilayah dan daerah serta perubahan zaman.

7. Tadarruj (gradual) dan mempertimbangkan urutan logis suatu beban (dari umum ke khusus, dari mudah ke sulit, dari lebih penting kepada yang penting, dari yang disepakati kepada yang diperselisihkan).

8. Waqïiyah (realistis) yang mempertimbangkan keadaan dan perubahan.

9. Mustaqbaliyah (futuristik), memperhitungkan/memprediksi masa depan. 


\section{BESTARI}

Vol. 17, No. 2, 2020

p-ISSN 1907-1337; e-ISSN 2807-6532

10. Tawazun (seimbang) yang memperhatikan pertumbuhan akal, fisik dan spiritual.

11. Wudhuh (jelas) dalam menyuguhkan gagasan, dengan mempergunakan bahasa yang mudah dipahami.

\section{Konsep Akhlak}

Akhlak secara etimologis berasal dari bahasa Arab jama' dari "khuluqun" yang menurut bahasa berarti budi pekerti, perangai, tingkah laku dan tabiat. Kalimat tersebut mengandung segi-segi persesuaian dengan perkataan Khalqun yang berarti kejadian, serta erat hubungannya dengan khaaliq dengan makhluk dan antara makhluk dengan makhluk (Sylviyanah, 2012, p. 193)

Dari pengertian etimologi akhlak bukan hanya tata aturan atau norma perilaku yang mengatur hubungan antar sesama manusia, tetapi juga norma yang mengatur hubungan antara manusia dengan Tuhan dan dengan alam semesta. Secara terminologis ada beberapa definisi tentang akhlak, diantaranya adalah sebagai berikut:

a. Menurut Imam Al Ghazali, akhlak adalah karakter yang menetap kuat didalam jiwa, yang menjadi sumber tidakan seseorang secara alamiah, spontan, tanpa motif dan keterpaksaan (Edidarmo, 2016, p. 59)

b. Menurut Abdul Karim Zaidan, akhlak adalah nilai-nilai dan sifat-sifat yang tertanam dalam jiwa, yang dengan sorotan dan timbangannya seseorang dapat menilai perbuatannya baik atau buruk, untuk kemudian memilih melakukan dan meninggalkannya.

Akhlak pada dasarnya melekat dalam diri seseorang, bersatu dengan perilaku atau perbuatan. Jika perilaku yang melekat itu buruk, maka disebut akhlak yang buruk atau akhlak mazmumah. Sebaliknya, apabila perilaku tersebut baik disebut akhlak mahmudah (Habibah, 2015)

Akhlak tidak terlepas dari aqidah dan syariah. Oleh karena itu, akhlak merupakan pola tingkah laku yang mengakumulasikan aspek keyakinan dan ketaatan sehingga tergambarkan dalam perilaku yang baik. Akhlak merupakan perilaku yang tampak (terlihat ) dengan jelas, baik dalam kata-kata maupun perbuatan yang memotivasi oleh dorongan karena Allah. Namun demikian, banyak pula aspek yang berkaitan dengan sikap batin ataupun pikiran, seperti akhlak diniyah yang berkaitan dengan berbagai aspek, yaitu pola perilaku kepada Allah, sesama manusia, dan pola perilaku kepada alam (Habibah, 2015, p. 74) 2. Akhlak Islam

Akhlak merupakan hasil dari usaha dalam mendidik dan melatih secara sungguh-sungguh terhadap berbagai potensi rohaniah yang terdapat dalam diri manusia. Apabila program pendidikan dan pembinaan dirancang dengan baik maka akan menghasilkan peserta didik/generasi penerus yang berakhlak baik. 
Dengan demikian pembentukan akhlak dapat didefinisikan sebagai usaha bersungguh-sungguh dalam rangka membentuk peserta didik/ generasi penerus dengan menggunakan sarana pendidikan dan pembinaan yang terprogram dengan baik dan dilaksanakan dengan konsisten. Pembentukan akhlak ini dilakukan berdasarkan asumsi bahwa akhlak adalah hasil usaha pembinaan, bukan terjadi dengan sendirinya. (Sylviyanah, 2012, p. 195)

3. Dasar Hukum Akhlak

Dalam ajaran Islam, dasar atau alat pengukur yang menyatakan baik buruknya sifat seseorang itu adalah Al-Qur`an dan As-Sunnah. Apa yang baik menurut Al-Qur`an dan As-Sunnah, itulah yang baik untuk dijadikan pegangan dalam kehidupan sehari-hari. Sebaliknya, apa yang buruk menurut Al-Qur `an dan As-Sunnah, itulah yang tidak baik dan harus dijauhi (Halimah, 2017, p. 24)

Bagi umat Islam, Al Qur`an dan Hadits Nabi Saw, adalah pedoman hidup seorang muslim. Allah Swt telah memerintahkan kepada umat Islam agar menjadikan Nabi Muhammad Saw sebagai teladan dalam semua hal. Apalagi dalam bidang pendidikan (tarbiyah) yang menjadi dasar bagi perubahan sikap dan pengetahuan (Aminah, 2017, p. 12) Banyak ayat yang memerintahkan manusia agar ittiba' pada Rasulullah Saw. Allah berfirman dalam Al-Qur'an surah An Nisaa', 4:59, "Wahai orang-orang yang beriman! Taatilah Allah dan taatilah Rasul (Muhammad), dan Ulil Amri (pemegang kekuasaan) diantara kamu. Kemudian, jika kamu berbeda pendapat tentang sesuatu, maka kembalikanlah kepada Allah (Al-Qur`an) dan Rasul (Sunnahnya), jika kamu beriman kepada Allah dan hari kemudian. Yang demikian itu, lebih utama (bagimu) dan lebih baik akibatnya" (QS An-Nisaa', 4:59), "Wahai orang-orang yang beriman! Taatlah kepada Allah dan Rasul-Nya, dan janganlah kamu berpaling dari-Nya, padahal kamu mendengar (Perintahperintah-Nya)" (QS. Al Anfaal, 8:20).

Segala sesuatu yang datang dari Nabi Muhammad Saw adalah haq (benar). Sehingga menjadi kewajiban bagi umat Islam untuk mengikuti arahan-arahan Nabi Saw. Al Qur `an telah menegaskan bahwa apa yang diucapkan oleh Nabi Saw semuanya adalah berasal dari wahyu, yang berarti terjamin keshahihannya, "dan tidaklah yang diucapkannya itu (AQur`an) menurut keinginannya (3) Tidak lain (Al-Qur`an itu) adalah wahyu yang diwahyukan (kepadanya) (4)" (QS. An Najm, 53:3-4).

Berdasarkan pada ayat-ayat di atas diketahui bahwa apa yang datang dari Nabi, baik berupa perkataan, perbuatan ataupun ketetapannya harus diterima dan menjadi sumber hukum dan pedoman bagi muslim dalam kehidupannya.

Dasar hukum akhlak ialah Al-Qur `an dan al-hadis yang merupakan dasar pokok ajaran Islam. Ketika 'Aisyah ditanya tentang akhlak Rasulullah, ia menjawab: Akhlak Rasulullah ialah Al-Qur 'an. Maksudnya adalah bahwa segala perilaku dan tindakan beliau, baik yang zhahir maupun bathin senantiasa mengikuti petunjuk dan ajaran Islam. 


\section{BESTARI}

Vol. 17, No. 2, 2020

p-ISSN 1907-1337; e-ISSN 2807-6532

Pribadi Rasulullah Saw merupakan contoh yang paling tepat untuk dijadikan teladan dalam membentuk pribadi yang akhlakul kharimah. Allah berfirman dalam QS Al-Azhab 33: 21: "Sungguh, telah ada pada (diri) Rasulullah itu suri tauladan yang baik bagimu (yaitu) bagi orang yang mengharap (rahmat) Allah dan (kedatangan) hari Kiamat dan yang banyak mengingat Allah (QS Al-Azhab 33: 21).

Dari ayat di atas dapat ditarik kesimpulan bahwa Rasulullah adalah sebaik-baiknya teladan, di dalam kehidupan kita harus mencontoh dan meneladani Rasulullah Saw. Kepada kita yang mengharapkan rahmat Allah dan keselamatan di dunia dan di akhirat, Al-Qur `an menyuruh kita agar meneladani Nabi Muhammad Saw. Rasulullah menjadi teladan untuk kita karena dalam berprilaku, beliau berpegang pada aturan dan ketentuan Allah Swt yang terkandung dalam Al-Qur`an. Jika kita ingin berakhlak menurut al-Qur`an maka kita harus meneladani Rasulullah Saw dan mencontoh perilaku beliau, dengan kata lain, kita harus mengikuti Sunnahnya (Halimah, 2017, p. 26)

2. Tujuan Akhlak

Pada dasarnya, tujuan pokok akhlak adalah agar setiap muslim berbudi pekerti, bertingkah laku, berperangai atau beradat istiadat yang baik sesuai dengan ajaran Islam. Di samping itu, setiap muslim yang berakhlak baik dapat memperoleh hal-hal berikut: Pertama, ridha Allah Swt. Orang yang berakhlak sesuai dengan ajaran Islam, senantiasa melaksanakan segala perbuatannya dengan hati yang ikhlas, semata-mata karena mengharapkan ridha Allah Swt. Kedua, kepribadian Muslim. Segala perilaku muslim, baik ucapan, perbuatan, pikiran ataupun kata hatinya mencerminkan sikap ajaran Islam. Ketiga, perbuatan yang mulia dan terhindar dari perbuatan tercela. Dengan bimbingan hati yang diridhai Allah Swt. Dengan keikhlasan, akan terwujud perbuatanperbuatan yang terpuji, yang seimbang antara kepentingan dunia dan akhirat serta terhindar dari perbuatan yang tercela (Irham, 2018, p. 26).

5. Macam-macam Akhlak

Secara garis besar, akhlak dapat dibedakan menjadi dua macam yaitu akhlak yang baik (akhlak mahmudah) dan akhlak yang buruk (akhlak mazmumah).

a. Akhlak Mahmudah

Akhlak Mahmudah Merupakan akhlak yang terpuji, mahmudah merupakan terjemahan dari ungkapan bahasa arab, Akhlak Mahmudah. Mahmudah merupakan bentuk maful dari kata hamida yang berarti dipuji. Akhlak terpuji disebut juga akhlak karimah (akhlak mulia) atau makarim al-akhlaq, atau al-ahlaq al-munjiyat (akhlak yang menyelamatkan pelakunya). Secara terminologi, menurut Al-Ghazali akhlak terpuji merupakan sumber kekuatan dan kedekatan kepada Allah Swt. Sehingga mempelajari dan mengamalkannya merupakan kewajiban individual setiap muslim. Menurut Al-Quzwani, akhlak terpuji merupakan ketetapan jiwa dengan perilaku baik dan terpuji. 
Menurut Al Marwadi, akhlak terpuji adalah perangai yang baik dan ucapan yang baik. Jadi, akhlak terpuji adalah ahklak yang sejalan dengan al Qur`an dan Sunnah. Yang termasuk akhlak karimah dijelaskan berdasarkan pembagian berikut : (1) akhlak kepada Allah Swt; (2) akhlak terhadap diri sendiri; (3) akhlak terhadap keluarga; (4) akhlak terhadap masyarakat; dan (5) akhlak terhadap lingkungan (Binaria, 2017, p. 11)

1) Akhlak terhadap Allah Swt

a) Mentauhidkan Allah Swt adalah pengakuan bahwa Allah Swt satusatunya yang memiliki sifat rububiyah (meyakini Allah Swt) dan uluhiyah (mengimani Allah Swt), serta kesempurnaan nama dan sifat.

b) Berbaik sangka (husnuzhan) merupakan salah satu akhlak terpuji kepada- Nya. Ciri akhlak terpuji ini adalah ketaatan yang sungguhsungguh kepada- Nya.

c) Zikrullah (mengingat Allah) adalah asas dari setiap ibadah kepada Allah Swt. Karena merupakan pertanda hubungan antara hamba dan pencipta pada setiap saat dan tempat.

d) Tawakal adalah gambaran keteguhan hati dalam menggantungkan diri hanya kepada Allah Swt. Dalam hal ini, Al Ghazali mengaitkan tawakal dengan tauhid, dengan penekanan bahwa tauhid sangat berfungsi sebagai landasan tawakal. Tawakal mempunyai hubungan erat dengan pemahaman manusia akan takdir, ridha, ikhtiar, sabar dan do'a (Binaria, 2017, p. 11)

2) Akhlak terhadap diri sendiri

a) Sabar, menurut Abu Thalib Al Makky, sabar adalah menahan diri dari dorongan hawa nafsu demi menggapai keridaan Tuhanmya dan menggantinya dengan bersungguh-sungguh menjalai cobaan-cobaan Allah Swt terhadapnya. Sabar dapat di definisikan dengan tahan menderita dan menerima cobaan dengan hati ridha serta menyerahkan diri kepada Allah Swt. Setelah berusaha. Selain itu, sabar bukan hanya bersabar terhadap ujian dan musibah, tetapi juga dalam hal ketaatan kepada Allah Swt, yaitu menjalankan perintahNya dan menjauhi larangan-Nya.

b) Syukur merupakan sikap seseorang untuk tidak menggunakan nikmat yang diberikan oleh Allah Swt dalam melakukan maksiat kepada-Nya. Bentuk syukur ini ditandai dengan keyakinan hati bahwa nikmat yang diperoleh berasal dari Allah Swt., bukan selainNya, lalu diikuti pujian oleh lisan, dan tidak menggunakan nikmat tersebut untuk sesuatu yang dibenci pemberinya.

c) Menunaikan Amanah adalah suatu sifat adab sikap pribadi yang setia, tulus hati, dan jujur dalam melaksanakan sesuatu yang dipercayakan kepadanya, berupa harta benda, rahasia, ataupun tugas kewajiban. Pelaksanaan amanat dengan baik disebut al-amin yang berarti dapat dipercaya, jujur, setia, dan aman.

d) Benar dan jujur, maksud dalam akhlak terpuji ini adalah berlaku benar dan jujur, baik dalam perkataan maupun dalam perbuatan. Benar dalam perkataan adalah mengatakan keadaan yang 


\section{BESTARI}

Vol. 17, No. 2, 2020

p-ISSN 1907-1337; e-ISSN 2807-6532

sebenarnya, tidak mengada-ada, dan tidak pula menyembunyikannya.

e) Menepati janji (al-wafa'), menurut Al Mawardi (386-450 H) merupakan salah satu kewajiban seorang pemimpin, bahkan menjadi tonggak berdirinya pemerintahan yang dipimpinnya. Sebab, jika seorang pemimpin tidak dapat dipercaya dengan janjinya terjadi banyak pembangkangan dari rakyat. Dengan demikian, tonggak pemerintah pun terancam roboh.

f) Memelihara kesucian diri (al-iffah) adalah menjaga diri dari segala tuduhan, fitnah, dan memelihara kehormatan. Upaya memelihara kesucian diri hendaknya dilakukan setiap hari agar diri tetap berada dalam status kesucian. Menurut Al Ghazali, dari kesucian diri akan lahir sifat-sifat terpuji lainnya, seperti kedermawanan, malu, sabar, toleran, qanaah, lembut, dan membantu (Binaria, 2017, p. 12)

3) Akhlak terhadap keluarga

a) Berbakti kepada kedua orang tua merupakan faktor utama diterimanya doa seseorang, juga merupakan amal saleh paling utama yang dilakukan oleh seorang muslim.

b) Bersikap baik kepada saudara, agama Islam memerintahkan untuk berbuat baik kepada sanak saudara atau kaum kerabat sesudah menunaikan kewajiban kepada Allah Swt dan ibu bapak.

4) Akhlak terhadap masyarakat

a) Berbuat baik kepada tetangga yaitu orang yang tinggal berdekatan dengan rumah. Ada atsar yang menunjukkan bahwa empat puluh rumah (yang berada di sekitar rumah) dari setiap penjuru mata angin. Dengan demikian, tidak diragukan lagi bahwa yang berdekatan dengan rumah adalah tetangga.

b) Suka menolong, seorang mukmin apabila melihat orang lain tertimpa musibah akan tergerak hatinya untuk menolong mereka sesuai dengan kemampuannya. Apabila tidak ada bantuan berupa benda, maka dapat dibantu dengan nasihat atau kata-kata yang dapat menghibur hatinya. Bahkan, bantuan jasa lebih diharapkan dari pada bantuan-bantuan lainnya.

5) Akhlak terhadap lingkungan

Akhlak yang diajarkan Al-Qur`an terhadap lingkungan bersumber dari fungsi manusia sebagai khalifah, yang mengandung arti pengayoman, pemeliharaan, serta pembimbingan agar setiap makhluk mencapai tujuan penciptaannya (Binaria, 2017: 14).

Adapun indikator dari akhlak terpuji atau akhlak mahmudah adalah: Pertama, perbuatan yang diperintah oleh ajaran Allah Swt dan Rasululllah Saw yang termuat dalam Al-qur`an dan As-sunnah.

(1) Perbuatan yang mendatangkan kemaslahatan dunia dan akhirat.

(2) Perbuatan yang meningkatkan martabat kehidupan manusia dimata Allah dan sesama manusia. 
(3) Perbuatan yang menjadi bagian tujuan dari syari'at islam, seperti: memelihara agama Allah, akal, jiwa, keturunan dan harta kekayaan

b. Akhlak Madzmumah

Akhlak Madzmumah merupakan akhlak yang tercela. Akhlak Madzmumah adalah segala bentuk yang bertentangan dengan akhlak mahmudah. Akhlak madzmumah merupakan tingkah laku yang tercela, yang dapat merusak keimanan seseorang dan menjatuhkan martabatnya sebagai manusia. Berikut yang termasuk akhlak tercela adalah sirik, kufur, nifak, fasik, takabur, ujub, dengki, gibah (mengumpat) dan Riya'.

1) Syirik adalah menyamakan sesuatu dengan Allah dalam hal-hal yang secara khusus dimiliki Allah.

2) Kufur adalah sifat dari orang kafir, yaitu perbuatan yang menyekutukan Allah.

3) Nifak dan fasik, nifak menurut syara' artinya menampakkan Islam dan kebaikan, tetapi menyembunyikan kekufuran dan kejahatan. Dengan kata lain, nifak adalah menampakkan sesuatu yang bertentangan dengan apa yang terkandung di dalam hati. Karena pelakunya masuk Islam melalui satu pintu, lalu keluar dari pintu yang lain. Sedangkan fasik adalah orang yang melakukan nifak.

4) Takabur dan ujub, takabur terbagi ke dalam dua bagian, yaitu batin dan lahir.

Takabur batin adalah perilaku dan akhlak diri, sedangkan takabur lahir adalah perbuatan-perbuatan anggota tubuh yang muncul dari takabur batin.

5) Dengki (hasad), yaitu perasaan yang timbul dalam diri seseorang setelah memandang sesuatu yang tidak dimiliki olehnya, tetapi dimiliki oleh orang lain, kemudian dia menyebarkan berita bahwa yang dimiliki orang tersebut diperoleh dengan tidak sewajarnya.

6) Gibah (mengumpat), Menurut Al Ghazali, gibah adalah menuturkan sesuatu yang berkaitan dengan orang lain yang apabila penuturan itu sampai pada yang bersangkutan, ia tidak menyukainya. menurut Ibnu Atsir, gibah adalah membicarakan keburukan orang lain yang tidak pada tempatnya walaupun keburukan itu memang ada padanya. Dari pendapat tersebut disimpulkan bahwa, ghibah adalah membicarakan aib orang lain yang tidak ada manfaatnya dan dapat menyakiti orang tersebut.

7) Riya' adalah salah satu sifat tercela yang harus dibuang jauh-jauh dalam jiwa kaum muslim karena riya' dapat menggugurkan amal ibadah. Riya' adalah memperlihatkan diri kepada orang lain atau sering disebut dengan pamer (Binaria, 2017: 16). adalah:

Sedangkan indikator perbuatan yang buruk atau akhlak yang tercela

a) Perbuatan yang didorong oleh hawa nafsu datangnya dari syetan

b) Perbuatan yang membahayakan kehidupan didunia maupun diakhirat

c) Perbuatan yang menyimpang dari syari'at islam 


\section{BESTARI}

Vol. 17, No. 2, 2020

p-ISSN 1907-1337; e-ISSN 2807-6532

d) Perbuatan yang menjadikan permusuhan kebencian

e) Perbuatan yang menimbulkan bencana bagi lingkungan dan kemanusiaan.

6. Ruang Lingkup Akhlak

Dilihat dari ruang lingkupnya, akhlak terbagi menjadi dua, yaitu:

a. Akhlak terhadap Khaaliq (Allah Swt)

Akhlak terhadap Allah bisa diartikan perbuatan atau tingkah laku yang seharusnya dilakukan oleh manusia sebagai makhluk yang lemah terhadap Allah. Orang yang beriman akan mengerti tentang kejadian alam semesta ini, niscaya ia akan menumpahkan harapannya hanya kepada Allah Swt, berharap akan menjadi hamba yang baik, berharap untuk mendapatkan rahmat-Nya, menjalannkan segala perintah-Nya dan menjauhi semua larangan-Nya.

b. Akhlak terhadap Makhluk (selain Allah Swt)

Akhlak terhadap manusia termasuk dirinya sendiri merupakan implikasi dari tumbuh dan berkembangnya iman seseorang. Salah satu indikator kuatnya iman seseorang terlihat dalam perilaku terhadap orang lain, misalnya akhlak sopan santun terhadap manusia. Akhlak terhadap manusia yaitu berkaitan dengan akhlak kepada orang tua, guru, tetangga dan lain sebagainya (Sylviyanah, 2012, p. 193)

7. Pembinaan Akhlak

Dalam Kamus Besar Bahasa Indonesia, pembinaan memiliki arti proses, perbuatan, cara membina, pembaharuan, penyempurnaan, usaha, tindakan dan kegiatan yang dilakukan secara berdaya guna untuk memperoleh hasil yang lebih baik (Daryanto, 2010, p. 105) Pembinaan akhlak merupakan tumpuan perhatian pertama dalam Islam. Hal ini dapat dilihat dari salah satu misi kerasulan Nabi Muhammad Saw yang utama yaitu untuk menyempurnakan akhlak yang mulia. Perhatian Islam yang demikian terhadap pembinaan akhlak ini dapat dilihat dari perhatian Islam terhadap pembinaan jiwa yang harus didahulukan dari pada pembinaan fisik, karena dari jiwa yang baik inilah akan lahir perbuatan-perbuatan yang baik yang pada tahap selanjutnya akan mempermudah menghasilkan kebaikan dan kebahagiaan pada seluruh kehidupan manusia, lahir dan batin (Irham, 2018, p. 34)

Pembinaan akhlak menurut Ibnu Maskawaih menitik beratkan kepada pembersihan diri dari sifat-sifat yang berlawanan dengan tuntutan Agama. Dengan pembinaan diharapkan dapat terwujudnya akhlak manusia yang ideal, anak yang bertaqwa kepada Allah Swt dan cerdas (Halimah, 2017, p. 36)

Dalam dunia pendidikan, pembinaan akhlak dititik beratkan kepada pembentukan mental peserta didik agar tidak menyimpang. Secara moralistik, pembinaan akhlak merupakan salah satu cara untuk membentuk pribadi yang bermoral, berbudi pekerti yang luhur dan bersusila. Dapat disimpulkan bahwa pembinaan akhlak adalah proses pelatihan untuk memperbaiki sifat yang tertanam dalam diri manusia 
agar melahirkan perbuatan-perbuatan yang lebih baik menurut pandangan akal dan agama.

Untuk membina akhlak peserta didik yang baik dan budi pekerti yang luhur, ada beberapa cara dalam memberikan pengetahuan agama dalam pembinaan akhlak peserta didik yaitu:

a. Melalui pembiasaan yang dilakukan sejak kecil dan berlangsung kontinyu. Berkenaan dengan ini imam al-Ghazali mengatakan bahwa kepribadian manusia itu pada dasarnya dapat menerima segala usaha pembentukan melalui pembiasaan. Jika manusia membiasakan berbuat jahat, maka akan menjadi orang jahat. Untuk ini al-Ghazali menganjurkan agar akhlak diajarkan, yaitu dengan cara melatih jiwa kepada pekerjaan atau tingkah laku yang mulia. Pembiasaan yang baik akan menentukan sikap tertentu pada anak seperti mengerjakan shalat, memberi salam kepada sesama, membantu orang lain sehingga anak terbiasa melakukan perbuatan baik yang akan menjadi akhlak yang baik pula.

b. Melalui pembinaan akhlak khususnya akhlak lahiriah dapat dilakukan dengan cara paksaan. Apabila pembinaan ini sudah berlangsung lama, maka paksaan tersebut sudah tidak lagi terasa sebagai paksaan. Seperti memaksakan anak menjalankan ibadah shalat, membaca Al-Qur`an, bersikap baik kepada orang tua dan sesama, bertutur kata yang sopan dan saling tolong menolong.

c. Melalui keteladanan dalam pendidikan adalah cara yang paling efektif dan berhasil dalam mempersiapkan peserta didik dari segi akhlak, membentuk mental dan sosialnya. Akhlak yang baik tidak dapat dibentuk hanya dengan pelajaran, intruksi dan larangan, sebab tabi'at jiwa untuk menerima keutamaan itu tidak cukup dengan hanya seorang guru mengatakan kerjakan ini dan jangan kerjakan itu. Pendidikan itu tidak akan sukses melainkan jika disertai dengan pemberian contoh teladan yang baik dan nyata. Cara yang demikian itu telah dilakukan oleh Rasulullah Saw sebagaimana dinyatakan dalam QS al- Ahzab/33: 21, "Sungguh, telah ada pada (diri) Rasulullah itu suri tauladan yang baik bagimu (yaitu) bagi orang yang mengharap (rahmat) Allah dan (kedatangan) hari Kiamat dan yang banyak mengingat Allah (QS Al-Azhab 33: 21).

8. Manfaat Akhlak

Manfaat orang yang berakhlak menurut A. Zainuddin dan Muhammad Jamhari, setiap muslim yang berakhlak yang baik dapat memperoleh hal-hal berikut:

a. Mendapatkan ridha Allah, orang yang melaksanakan segala perbuatan karena mengharap ridha Allah berarti ia telah ikhlas atas segala amal perbuatannya.

b. Membentuk keperibadian Muslim, segala ucapan, perbuatan, pikiran dan kata hatinya mencerminkan sikap ajaran Islam.

c. Mewujudkan perbuatan yang mulia dan terhindarnya perbuatan tercela, dengan bimbingan hati yang diridai Allah dengan keikhlasan, 


\section{BESTARI}

Vol. 17, No. 2, 2020

p-ISSN 1907-1337; e-ISSN 2807-6532

maka akan terwujud perbuatan-perbuatan yang terpuji, yang seimbang antara kepentingan dunia dan akhirat serta terhindar dari perbuatan tercela (Halimah, 2017, p. 32)

Dari uraian di atas dapat disimpulkan bahwa orang yang berakhlak akan memperoleh kebahagian baik di dunia maupun akhirat, selalu mendapatkan pertolongan serta kemudahan dari Allah. Selain itu juga, disenangi serta mendapatkan tempat yang baik dihati orang lain, dan mendapatkan kebahagian di dunia maupun di akhirat. Di mana hidup bahagia merupakan hidup yang sejahtera dan selalu mendapat ridha Allah, pertolongan dari Allah, juga selalu disenangi oleh sesama makhluk dan terhindar dari perbuatan tercela, dengan bimbingan hati yang diridai Allah dengan keikhlasan, maka akan terwujud perbuatan-perbuatan yang terpuji, yang seimbang antara kepentingan dunia dan akhirat.

\section{B. Konsep Peserta Didik}

Peserta didik adalah makhluk yang berada dalam proses perkembangan dan pertumbuhan menurut fitrahnya masing-masing, yang memerlukan bimbingan dan pengarahan yang konsisten menuju kearah titik optimal kemampuan fitrahnya (Agustina, 2018 , p. 1) Peserta didik juga merupakan potensi diri melalui proses pembelajaran yang tersedia pada jalur, jenjang, dan jenis pendidikan tertentu. Peserta didik juga dapat diartikan sebagai orang yang mempunyai pilihan untuk menempuh ilmu sesuai dengan cita-cita dan dan harapan masa depan (Rahman, 2017, p. 2). Peserta didik juga dapat diartikan sebagai orang yang tengah mencari ilmu, baik pada lembaga pendidikan secara formal maupun lembaga pendidikan non formal (Saehudin, 2016, p. 82)

Di dalam UU No.20 Tahun 2003 Tentang sistem Pendidikan Nasional (Sisdiknas), peserta didik didefinisikan sebagai manusia yang berusaha mengembangkan potensi diri melalui proses pembelajaran pada jalur pendidikan baik formal maupun non formal, pada jenjang pendidikan dan jenis pendidikan tertentu (Aminah, 2017, p. 82)

Peserta didik adalah orang yang sedang berada pada fase pertumbuhan dan perkembangan baik secara fisik maupun psikis, pertumbuhan dan perkembangan merupakan ciri dari seseorang peserta didik yang perlu bimbingan dari seorang pendidik. Manusia harus sadar akan potensi rohani yang dimilikinya karena puncak kebutuhan manusia adalah mencintai dan dicintai Tuhan. Al-Ghazali seorang pemikir muslim yang masyhur dan sering disebut sebagai Hujjatul Islam. Pendidikan dijadikannya sebagai taqarub ila Allah tanpa alasan lain lagi kecuali satu. Dari pemikiran Al-Ghazali ini akan terllihat bagaimana mengontrol potensi rohani peserta didik agar terkontrol dalam perjalanan mencari ilmu pengetahuan yang kaya akan nilai (Maulana, 2015, p. 1)

Berdasarkan beberapa pengertian diatas dapat disimpulkan bahwa peserta didik pada hakikatnya adalah pribadi sebagai anggota masyarakat yang berusaha meningkatkan berbagai potensi diri melalui proses 
pendidikan atau pembelajaran untuk menjadi pribadi yang sesuai dengan tujuan pendidikan yang diharapkan.

Karakter peserta didik adalah sifat-sifat yang dimiliki individu sebagai peserta didik yang dapat diidentifikasi sebagai orang yang mencari ilmu pengetahuan dengan sungguh-sungguh untuk bekal dimasa depan baik untuk kehidupan dunia maupun kehidupan akhirat (Saehudin, 2016). Karakter peserta didik diantaranya:

a. Peserta didik menjadikan Allah sebagai sebagai motivator utama dalam menuntut ilmu. Ayat yang pertama kali turun kepada Baginda Nabi Muhammad Saw yaitu surat Al-alaq ayat 1-5 yang artinya. "Bacalah dengan (menyebut)nama Tuhanmu yang menciptakan. Telah menciptakan manusia dari segumpal darah. Bacalah, dan Tuhanmulah yang maha mulia. Yang mengajar manusia (manusia) dengan pena. Dia mengajarkan manusia apa yang tidak diketahuinya". Ayat tersebut menyuruh manusia untuk menuntut ilmu dengan kata iqra. Namun dalam aplikasinya, pencarian itu hendaklah dilakukan dengan niat ikhlas dan menjadikan Allah sebagai motivator dalam menuntut ilmu tersebut, baik dalam ilmu agama maupun ilmu umum.

b. Senantiasa mendalami pelajaran yang maksimal, yang ditunjang dengan persiapan dan kekuatan mental, ekonomi, fisik dan psikis.

c. Senantiasa mengadakan perjalanan (rihlah) dan melakukan riset dalam rangka menuntut ilmu karena ilmu tidak hanya terdapat dalam satu majelis, tetapi dapat dilakukan di tempat dan majelismajelis lain.

d. Memiliki tanggung jawab

e. Ilmu yang dimilikinya dapat dimanfaatkan.

Fungsi peserta didik dalam interaksi belajar-mengajar adalah sebagai subjek dan objek. Sebagai subjek, karena peserta didik menentukan hasil belajar dan sebagai objek, karena peserta didiklah yang menerima pelajaran dari guru. Guru mengajar dan peserta didik belajar. Jika tugas pokok guru adalah "mengajar", maka tugas pokok peserta didik adalah "belajar". Keduanya amat berkaitan dan saling bergantungan, satu sama lain tidak terpisahkan dan berjalan serempak dalam proses belajarmengajar.

Dalam Undang-Undang Nomor 20 Tahun 2003 Tentang Sistem Pendidikan Nasional Bab V Pasal 12 disebutkan:

a. Setiap peserta didik pada setiap satuan pendidikan berhak:

1) Mendapatkan pendidikan agama sesuai dengan agama yang dianutnya dan diajarkan

2) Mendapatkan pelayanan pendidikan sesuai dengan bakat, minat, dan kemampuaannya

3) Mendapatkan beasiswa bagi yang berprestasi yang orang tuanya tidak mampu membiayai pendidikannya

4) Mendapatkan biaya pendidikan bagi mereka yang orang tuanya tidak mampu membiayai pendidikannya 


\section{BESTARI}

Vol. 17, No. 2, 2020

p-ISSN 1907-1337; e-ISSN 2807-6532

5) Pidah ke program pendidikan pada jalur dan satuan pendidikan lain yang setara

6) Menyelesaikan program pendidikan sesuai dengan kecepatan belajar masing-masing dan tidak menyimpang dari ketentuan batas waktu yang ditetapkan.

b. Setiap peserta didik berkewajiban:

1) Menjaga norma-norma pendidikan untuk menjamin keberlangsungan proses dan keberhasilan pendidikan

2) Ikut menanggung biaya penyelenggaraan pendidikan, kecuali bagi peserta didik yang dibebaskan dari kewajiban tersebut sesuai dengan peraturan perundang-undangan yang berlaku.

Dapat ditarik kesimpulan bahwa tugas utama peserta didik adalah belajar, menunutut ilmu sebanyak-banyaknya, mengembangkan bakat yang ia miliki. Akan tetapi tugas peserta didik bukan hanya belajar dalam ranah kognitif saja tetapi yang lebih penting dari itu, yakni menjadi pribadi yang berakhlak. Hal ini sejalan dengan tujuan pendidikan nasional yaitu mengembangkan potensi peserta didik agar menjadi manusia yang beriman dan bertakwa kepada Tuhan Yang Maha Esa, berakhlak mulia, sehat, berilmu, cakap, kreatif, mandiri, dan menjadi warga negara yang demokratis serta bertanggung jawab.

2. Sifat-sifat yang harus dimiliki peserta didik

Sebagai upaya mencapai tujuan pendidikan Islam, peserta didik hendaknya memiliki dan menanamkan sifat-sifat yang dalam diri dan kepribadiaannya, dan memiliki karakter kuat sebagai peserta didik atau pelajar. Di antara sifat-sifat ideal yang perlu dimiliki peserta didik misalnya: berkemauan keras atau pantang menyerah, memiliki motivasi yang tinggi, sabar, tabah, tidak mudah putus asa dan lain sebagainya.

Peserta didik perlu disempurnakan dengan empat akhlak dalam menuntut ilmu, di antaranya:

a. Peserta didik harus mempunyai tujuan menuntut ilmu dalam rangka menghiasi jiwa dengan sifat keimanan, mendekatkan diri kepada Allah.

b. Peserta didik harus tabah dalam memperoleh ilmu pengetahuan dan sabar dalam menghadapi tantangan dan cobaan yang datang.

c. Peserta didik harus ikhlas dalam menuntut ilmu dan menghormati guru atau pendidik, berusaha memperoleh kerelaan dari guru dengan mempergunakan beberapa cara yang baik.

d. Peserta didik harus berusaha dengan sungguh-sungguh (berjihad) dalam menuntut ilmu serta diiringi dengan do'a kepada Allah agar berhasil dalam menuntut ilmu (Irawan, 2018, p. 39)

Sifat-sifat tersebut menjadi mutlak dimiliki oleh seorang peserta didik, hal ini dikarenakan menuntut ilmu dan menerima pendidikan pada hakekatnya adalah mencari ridha Allah SWT. Selain itu, keridhoan seorang guru terhadap peserta didik nya lebih mulia dibandingkan ilmu dan pendidikan itu sendiri. 


\section{HASIL PENELITIAN DAN PEMBAHASAN}

Akhlak Peserta Didik SD Inpiratif Al-Ilham Kota Banjar

Dari hasil observasi yang peneliti lakukan, akhlak dirangkung dalam 2 aspek akhlak yakni: akhlak terhadap Allah dan akhlak terhadap manusia. Berikut penjelasannya.

Tabel 1. Indikator Akhlak

\begin{tabular}{|c|c|c|}
\hline No & Indikator & Akhlak \\
\hline 1 & $\begin{array}{ll}\text { a. } & \text { Melasanakan sholat } \\
& \text { berjamaah } \\
\text { b. Melaksanakan sholat sunnah } & \text { Duha dan Qiyamullail } \\
\text { c. Melakukan wudhu dengan } \\
\text { tertib dan juga benar } \\
\text { d. Senantiasa menutup aurat } \\
\text { e. Membaca dzikir setiap } \\
\text { selesai sholat } \\
\text { f. Menghafal Al-qur'an beserta } \\
\text { terjemahnya dan hafalan } \\
\text { Hadist Nabi. }\end{array}$ & 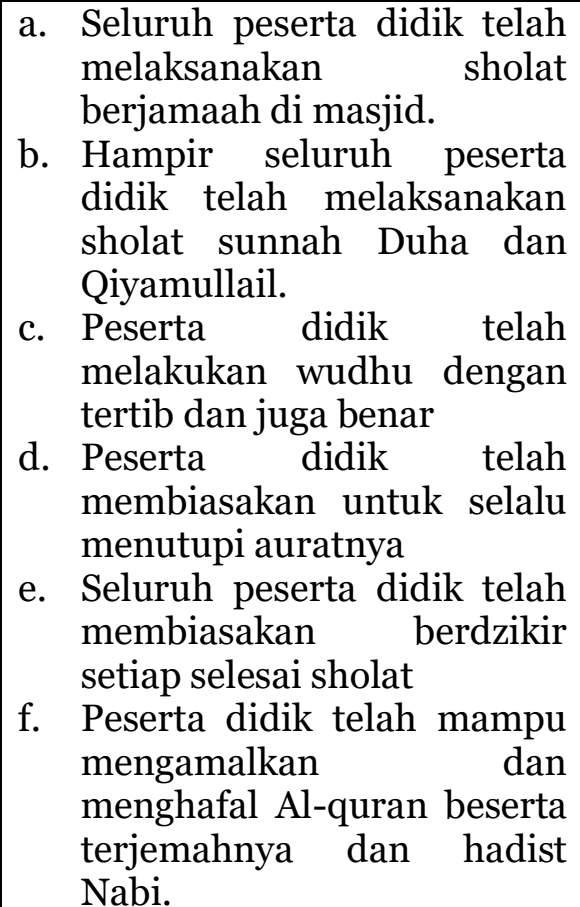 \\
\hline 2 & $\begin{array}{l}\text { a. Berbakti kepada orang tua, } \\
\text { menghormati yang lebih tua, } \\
\text { dan menyayangi yang lebih } \\
\text { muda } \\
\text { b. Saling tolong menolong } \\
\text { c. Belajar amar ma'ruf nahi } \\
\text { munkar } \\
\text { d. Bertutur bahasa yang sopan } \\
\text { dan berbuat baik terhadap } \\
\text { orang lain }\end{array}$ & $\begin{array}{l}\text { a. Peserta didik terlihat akhlak } \\
\text { nya berbakti kepada orang } \\
\text { tua, menghormati yang lebih } \\
\text { tua, dan menyayangi yang } \\
\text { lebih muda } \\
\text { b. Peserta didik sudah } \\
\text { memiliki jiwa solidaritas } \\
\text { yang tinggi sehingga saling } \\
\text { tolong menolong terhadap } \\
\text { orang lain didik telah } \\
\text { c. Peserta ba da } \\
\text { mengerjakan hal-hal baik } \\
\text { dan menjauhi apa yang } \\
\text { dilarang oleh Allah SWT } \\
\text { d. Hampir seluruh peserta }\end{array}$ \\
\hline
\end{tabular}


BESTARI

Vol. 17, No. 2, 2020

p-ISSN 1907-1337; e-ISSN 2807-6532

\begin{tabular}{|l|l|l|}
\hline No & \multicolumn{1}{|c|}{ Indikator } & \multicolumn{1}{|c|}{ Akhlak } \\
\hline & & didik telah bertutur bahasa \\
& & yang sopan, namun ada \\
& & beberapa peserta didik yang \\
& masih bertutur bahasanya \\
& kurang baik. \\
\hline
\end{tabular}

SD Inspiratif Al-Ilham Kota Banjar sangat mengedepankan pendidikan agama dan akhlak bagi peserta didik. Yaitu dengan pembinaan atau disebut Bina Pribadi Islam. Dimana Bina Pribadi Islam ini menjadi salah satu program sekolah yang sangat berperan penting di SD Inspiratif Al-Ilham Kota Banjar dalam pembinaan akhlak peserta didik.

Implementasi Bina Pribadi Islam Dalam Membina Akhlak Peserta Didik di SD Inspiratif Al Ilham Kota Banjar

1. Gambaran Umum Bina Pribadi Islam

a. Latar belakang Bina Pribadi Islam

SD Inspiratif Al-Ilham Kota Banjar merupakan tingkat satuan pendidikan sekolah dasar islam yang memiliki suatu program pembinaan akhlak peserta didik yakni sebuah program yang bernama Bina Pribadi Islam. Pada Bina Pribadi Islam ini, peserta didik diarahkan serta di didik dalam rangka membentuk seorang pribadi yang islami, berjiwa islami, dan berkarakter islami.

Hadirnya Bina Pribadi Islam di SD Inspiratif Al-Ilham Kota Banjar ini yaitu merupakan salah satu program yang masuk dalam kurikulum pembelajaran yang ada di SD Inspiratif Al-Ilham Kota Banjar, dimana Bina Pribadi Islam ini merupakan sebuah Program sekaligus kurikulum dan masuk dalam proses belajar mengajar. Seperti yang terungkap oleh seorang wakasek kurikulum saat proses wawancara berlangsung Berdasarkan wawancara dengan Wakasek Kurikulum yakni Ibu Ena Marlina, S.Pd., dapat disimpulkan bahwa di SD Inspiratif Al-Ilham Kota Banjar ini, karakter-karakter yang dibutuhkan adalah kepribadian yang islami, dia mempunyai inisiatif untuk menjaga diri dan membina diri serta lingkungan sehingga terhindar dari usaha dan pengaruh budaya yang bertentangan dengan nilai-nilai keislaman."

b. Tujuan Bina Pribadi Islam

Dari hasil wawancara yang telah dilaksanakan dengan Wakasek Kurikulum SD Inspiratif Al-Ilham Kota Banjar, Penulis dapat mengambil kesimpulan bahwasanya, didalam tingkat satuan sekolah pada umumnya tidak hanya mengutamakan pada segi kognitif/ ilmu pengetahuan saja, tetapi di dalam tingkat satuan sekolah dasar sangat memerlukan pembinaan atau suatu proses pembelajaran yang menanamkan karakter, terutama dalam hal karakter yang berjiwa islami, karena pada usia dini sangat penting untuk anak mengetahui hal-hal positif yang mereka dapati terutama dalam hal akhlak. Hingga muncullah di SD Inspiratif Al-Ilham 
Kota Banjar ini adalah suatu pembinanaan yang merupakan pembinaan akhlak anak dimana, sekolah sangatlah fokus dalam menangani zaman yang semakin maju ini, yakni dengan begitu banyak program-program sekolah yang memiliki tujuan sama, yakni sama sama untuk memperbaiki dan membina akhlak peserta didik, namun tidak hanya menekankan pada segi kognitif saja. Hal ini juga sangat disambut dan direspon baik, oleh para wali murid dengan adanya pengisian buku evaluasi pada setiap peserta didik, dan orangtua pun ikut serta mendampingi dan mengawasi anak-anak nya dirumah dalam memenuhi tugas-tugas ataupun kompetensi yang harus dicapai pada buku evaluasi tersebut. Yang mana dalam hal ini merupakan hasil dari program Bina Pribadi Islam.

2. Implementasi Bina Pribadi Islam di SD Inspiratif Al-Ilham Kota Banjar

SD Inspiratif Al-Ilham Kota Banjar merupakan salah satu Sekolah Dasar yang memadukan antara sekolah umum dengan sekolah Islam Terpadu, mengintegrasikan kurikulum Nasional dengan Nilai-Nilai Islami yang mengacu pada standarisasi mutu atau menganut pada JSIT Indonesia ( Jaringan Sekolah Islam Terpadu). SD Inspiratif Al-Ilham Kota Banjar telah menciptakan sebuah keseimbangan serta keselarasan yakni memadukan antara ilmu pengetahuan dunia dengan ilmu pengetahuan akhirat serta visi dan misi sekolah yang islami dan berkompetensi.

Berdasarkan dari hasil wawancara dengan Wakasek Kurikulum sekaligus penanggung jawab BPI SD Inpiratif Al Ilham Kota Banjar, beliau adalah ibu Ena Marlina S.Pd., mengatakan bahwa pembinaan akhlak peserta didik masuk kedalam program, dan masuk dalam waktu pembelajaran.

Menurut Nasution \& Manurung dalam buku Patologi Sosial dan Pendidikan Islam Keluarga. Pembinaan akhlak yaitu pembinaan yang berhubungan tentang, pembinaan dengan menggunakan keteladanan, pembinaan dengan pembiasaan, dan pembinan dengan nasihat.

a. Pembinaan dengan keteladanan

Pembinaan dengan metode keteladanan berarti pembinaan dengan memberi contoh. Baik berupa tingkah laku, sifat, cara berfikir dan sebagainya. Hal itu karena dalam belajar manusia pada umumnya, lebih mudah menangkap yang kongkrit dari pada yang abstrak. Jadi sudah jelas bahwa metode pembinaan dengan keteladanan merupakan hal yang paling berhasil dalam proses pembinaan akhlak peserta didik. (Juraini, 2018, p. 37)

Dari hasil wawancara yang telah penulis lakukan bahwasanya, dalam membina Bina Pribadi Islam (BPI) pada peserta didik juga sangat menekankan pada pemberian keteladanan atau memberi contoh yang baik untuk peserta didik. Karena seorang guru adalah panutan yang ditiru perilaku dan lisan nya serta menjadi suri tauladan bagi para peserta didik. Caranya yaitu oleh seorang murobbi atau guru pada Bina Pribadi Islam 


\section{BESTARI}

Vol. 17, No. 2, 2020

p-ISSN 1907-1337; e-ISSN 2807-6532

yakni dengan cara ceramah saat BPI berlangsung, selain itu juga dengan keteladanan langsung dari seorang pendidik.

Mendidik peserta didik dengan tauladan adalah salah satu cara yang paling efektif karena memberikan keteladanan yang baik, sehingga peserta didik pun akan lebih mudah untuk meniru atau mengikutinya, dari semua apa yang dia lihat dari seorang pendidik. Wakasek Kurikulum ibu Ena Marlina, S.Pd., mengatakan pada saat wawancara bahwasanya memang pada setiap peserta didik itu mempunyai potensi untuk menjadi baik, namun peserta didik juga tidak akan serta merta mengikuti kebaikan tersebut sesuai dengan fitrahnya. Yang menjadi peran paling utama adalah seorang pendidik yang sangat berfungsi mengadakan suatu pembinaan tersebut. Sehingga peserta didik akan mengikuti sesuai apa yang dikatakan dan dilakukan oleh pendidiknya. Namun ketika pendidik hanya dapat mengarahkan saja tanpa mengaplikasikanya suatu contoh yang baik bagi peserta didik, maka disinilah yang amat sulit untuk para peserta didik mengikuti dan mencontoh pendidiknya untuk dapat meniru dan mempraktekanya langsung. Dari hasil observasi penulis di SD Inspiratif Al-Ilham Kota Banjar, penulis mendapatkan data tentang pembinaan akhlak peserta didik dimana, peserta didik dibina untuk selalu berbakti kepada orang tua, menghormati yang lebih tua, menyayangi yang lebih muda, dan saling tolong menolong terhadap orang lain.

b. Pembinaan dengan Pembiasaan

Metode Pembiasaan dalam pembinaan akhlak harus dilakukan sejak kecil dan berlangsung seacara terus menerus, dalam hal ini AlGhazali mengatakan bahwa kepribadian manusia biasanya menerima usaha pembentukan melalui pembiasaan. Jika manusia membiasakan berbuat jahat, maka ia akan menjadi orang jahat. Untuk itu Al-Ghazali menganjurkan agar pembinaan akhlak diajarkan dengan cara melatih jiwa atau pekerjaan kepada tingkah laku yang mulia. Jika seorang peserta didik dihendaki untuk menjadi peserta didik yang suka menolong, maka peserta didik harus dibiasakan melakukan pekerjaan untuk menolong orang lain (Juraini, 2018, p. 37)

Metode pembiasaan kepada peserta didik terutama dalam hal akhlak, etika, sopan santun berbicara dll, dapat diaplikasikan atau diamalkan serta tertanam pada setiap diri peserta didik dalam kehidupan sehari-hari. Menerapkan sebuah metode kebiasaan ini adalah salah satu cara yang akan dapat menumbuhkan akhlakul karimah/ akhlak yang mulia kepada peserta didik, jiwa yang bersih, serta etika yang sesuai dalam syari'at Islam. Hal ini juga dipertegas oleh Wakasek kurikulum Ibu Ena Marlina, S.Pd., mengatakan:

'... selain itu juga para peserta didik diarahkan untuk dapat membiasakan hal-hal yang baik/positif misalnya, shalat dhuha serta shalat dengan selalu berjama'ah dimasjid dilikungkungan sekolah." Dari hasil observasi tersebut dapat dikatakan bahwa pembiasaan yang baik selalu senantiasa ditanamkan pada seluruh peserta didik dan seluruh guru beserta pendidik 
lainnya di SD Inspiratif Al-Ilham Kota Banjar. Berdasarkan hasil observasi di SD Inspiratif Al-Ilham Kota Banjar peserta didik sudah dibiasakan untuk melakukan sholat berjamaah, sholat sunnah dhuha dan qiyamullail, membaca dzikir setiap selesai sholat dan lain-lain.

c. Pembinaan dengan Nasehat

Metode pembinaan akhlak melalui pemberian nasehat dapat menanamkan pengaruh yang baik dalam jiwa, apabila digunakan dengan cara yang dapat mengetuk qalbu. Sementara itu cara pemberian nasehat kepada peserta didik, para pendidik menekankan pada ketulusan dan disertai dengan keihklasan. Dari penjelasan diatas maka seorang guru harus menasehati peserta didik dengan cara yang lembut ataupun cara yang tepat. Sehingga akan terbuka pintu hati peserta didik untuk berbuat kebaikan dan peserta didik akan lebih menerima nasehat atau arahan dari gurunya (Juraini, 2018)

Pendidikan melalui nasehat dan pemahaman serta peringatan akan kebaikan dan suatu kebenaran, dengan melalui cara menyentuh qalbu dan menggugah melalui mengamalkanya. Serta melalui nasehat dapat diberikan suatu pendidikan yang dapat merubah akhlak kearah yang lebih baik, dimana suatu nasehat sendiri akan efektif jika dibarengi dengan suatu keteladanan yang baik dari pemberi nasehat.

Dari hasil observasi yang penulis lakukan di SD Inspiratif Al-Ilham Kota Banjar, setelah mereka mendapatkan nasehat dan pemahaman setiap harinya dari guru atau murobbi, mereka menerapkannya langsung dalam kehidupan sehari-hari. Seperti nasehat yang diulang-ulang bahwa kita harus saling berbagi, maka telah terlihat oleh penulis bahwa peserta didik memang selalu saling berbagi dan contoh lain sebagainnya. Selain itu, pembinaan akhlak melalui nasehat sangat berkaitan dengan keteladanan dan pembiasaan. Jadi apabila nasehat sudah diberikan maka secara sistematis akan di aplikasikanya dalam bentuk keteladanan dan pembiasaan dalam kehidupan sehari-hari.

Hasil dari wawancara dengan Wakasek kurikulum SD Inspiratif Al-Ilham Kota Banjar juga mengatakan bahwasanya yang paling utama adalah sangat meng-unggulkan dalam bidang karaker, mencetak pribadipribadi yang unggul, generasi-generasi yang bukan hanya siap untuk diri sendiri tapi, dia juga perduli terhadap lingkungan.

Dilihat dari tujuan utama di SD Inspiratif Al-Ilham Kota Banjar, disinilah yang semakin menarik oleh penulis untuk lebih dalam lagi teliti, mengenai program sekolah di SD Inspiratif Al-Ilham Kota Banjar. Untuk melihat secara langsung bagaimana proses berlangsungnya suatu pembinaan akhlak, di dalam Bina Pribadi Islam, karena banyak sekali yang kita lihat pada umumnya, pada tingkat sekolah dasar masih jarang sekali yang mengutamakan serta unggul dalam pembinaan karakterkarakter Islami yang seperti ini, biasanya sudah bukan menjadi rahasia umum lagi, bahwa sekolah dasar hanya mengedepankan segi kognitif atau ilmu pengetahuan saja, padahal realitanya pada masa penanaman akhlak peserta didik ini sangat dibutuhkan di tingkat sekolah dasar. Tetapi 


\section{BESTARI}

Vol. 17, No. 2, 2020

p-ISSN 1907-1337; e-ISSN 2807-6532

belum banyak sekolah yang mempunyai program khusus pembinaan akhlak pada peserta didik.

3. Hasil Bina Pribadi Islam Dalam Membina Akhlak Peserta Didik Di SD Inspiratif Al-Ilham Kota Banjar

Dari hasil wawancara dengan wakasek kurikulum ibu Ena Marlina, S.Pd., beliau mengatakan bahwa Bina Pribadi Islam itu masuk kedalam pembelajaran, dan masuk ke dalam mata pelajaran, serta merupakan program wajib di SD Inspiratif Al-Ilham Kota Banjar. Penulis dapat menganalis sesuai dengan hasil serta saat terjun dilapangan maupun observasi di SD Inspiratif Al-Ilham Kota Banjar, bahwa sekolah telah berupaya semaksimal mungkin dalam membina akhlak para peserta didik dengan program-program sekolah yang sangat menunjang, segenap guruguru juga sudah berupaya semaksimal mungkin dalam membina dan mendidik peserta didik dengan karakter Islami. Program telah dilaksanakan dan kewajiban serta tanggung jawab seorang guru telah dijalankan, tetapi implementasi dari peserta didik nya berbeda-beda, seiring berjalanya waktu dengan adanya program sekolah dalam membina karakter peserta didik.

Penulis menganalisis data yang diperoleh berdasarkan hasil observasi dan wawancara, secara umum mengenai Implementasi Bina Pribadi Islam dalam membina akhlak peserta didik di SD Inspiratif AlIlham Kota Banjar yaitu pembinaan dengan keteladanan, kebiasaan, serta nasehat namun dalam ke tiga aspek tersebut juga mengacu pada sebuah SKL (Standar Kelulusan) dan menjadi acuan dari ke tiga aspek diatas. Serta yang harus peserta didik capai, dimana SKL ini terdapat Kompetensi, Materi, dan Indikator indikator dimana dari materi yang telah diberikan dalam Bina Pribadi Islam yang menjadi output bagi setiap peserta didik. Menurut kepala sekolah ibu Rina Maryani, S.Pd., Adapun SKL (Standar Kelulusan) asalnya dari JSIT, (Jaringan Sekolah Islam Terpadu), aqidah lurus, ibadah nya harus benar, akhlak nya harus baik, ranah nya bukan hanya akhlak saja, ranah nya itu ada 7 , diantaranya berhubungan dengan Al-qur'an, kepribadianya matang, tidak mudah menangis, percaya diri, dan punya jiwa kepemimpinan. Hasil dari Bina Pribadi Islam dalam membina akhlak peserta didik di SD Inspiratif AlIlham Kota Banjar yaitu:

1. Bertutur kata dengan bahasa yang sopan dan berbuat baik terhadap orang lain

Saat melakukan observasi penulis melihat bahwasanya peserta didik yang berada dilingkungan SD Inspiratif Al-Ilham Kota Banjar ketika bergaul, bertutur kata cukup baik, serta sangat menghormati dengan orang yang lebih tua, terutama ketika seorang peniliti datang langsung ke SD Inspiratif Al-Ilham Kota Banjar melihat di kelas secara langsung dan lingkungan sekolah terdapat seluruh peserta didik sangat ramah, senyum serta menyapa dengan sopan dan santun, tidak ada kegaduhan dari peserta didik, hanya dari beberapa peserta didik saja yang berbicara nya 
dengan nada yang keras atau kasar, tetapi mayoritas peserta didik memiliki tutur kata yang sangat baik serta sopan dan santun, hal ini disebabkan dari keseluruhan tenaga pendidik yang berada di SD Inspiratif Al-Ilham Kota Banjar.

2. Senantiasa Menutup Aurat

SD Inspiratif Al-Ilham Kota Banjar, baik aparatur sekolah/ segenap dewan guru dan seluruh peserta didik yang berada di luar lingkup umum, semua nya wajib menutup aurat. Dalam hal menutup aurat, seluruh guru perempuanya sudah mengenakan hijab yang berdasarkan contoh dari syari'at islam, yakni hingga menutupi dada, dan ukuranya cukup besar hingga menutupi di bagian bawah pusar. Penulis telah mengamati, bahwasanya ketika berpakaian peserta didik sudah sangat rapih, sesuai dengan peraturan yang ada di SD Inspiratif Al-Ilham Kota Banjar, mengenakan hijab nya sudah hampir mengikuti contoh dari tauladan guru, peserta didik perempuan telah diberikan contoh dan aktualisasi dari pendidik tentang bahwasanya seorang wanita/ perempuan itu hukumnya sangat wajib harus menutup auratnya dalam kehidupanya sehari-hari, baik dilingkungan sekolah maupun dilingkungan masyarakat. Karena Allah Swt, telah mengajarkan kepada seluruh umat Nabi Muhammad Saw bahwasanya tertulis dalam Al-Qur`an yang artinya: sesungguhnya telah ada pada diri Rasul itu suri tauladan yang baik. Berdasarkan observasi dengan guru atau murobbi BPI dan hasil buku evaluasi siswa, terlihat siswa sudah menghindari hal-hal yang dapat menimbulkan dosa.

3. Belajar amar ma'ruf nahi mungkar

Berdasarkan observasi, peserta didik sudah belajar materi tentang amar ma'ruf nahi mungkar, terlihat mayoritas peserta didik sudah mengerjakan hal-hal yang baik seperti, giat dalam belajar, tolong menolong, sopan santun, tidak bersuudzon terhadap orang lain, dan juga tidak suka berbisik-bisik ketika para peserta didik sedang berkumpul.

4. Melakukan wudhu dengan tertib dan benar

Pada pembelajaran Bina Pribadi Islam seluruh peserta didik belajar tentang bagaimana cara berwudhu yang tertib dan juga benar. Semua pelajaran itu disampaikan langsung oleh guru atau murobbi tiap kelas, bahkan di SD Inpiratif Al-Ilham Kota Banjar ini ketika pembelajaran bukan hanya menyampaikan materinya saja, namun memperaktekannya langsung supaya para peserta didik dapat memahaminya. Selain itu ketika akan melaksanakan sholat berjamaah disekolah, setiap peserta didik ketika berwudhu selalu dipantau oleh guru yang bertugas, dari mulai berwudhu sampai dengan membaca do'a setelah berwudhu. Ketika ada yang belum benar langsung ditegur dan diajarkan.

5. Melaksanakan Shalat Berjama'ah

Dari hasil observasi yang telah penulis lakukan, bahwasanya terlihat pada seluruh peserta didik sudah melaksanakan shalat dengan berjama'ah di masjid yang ada di SD Inspiratif Al-Ilham Kota Banjar. Dari hasil observasi tersebut dapat dikatakan bahwa pembiasaan yang baik selalu senantiasa ditanamkan pada seluruh peserta didik Di SD Inspiratif 


\section{BESTARI}

Vol. 17, No. 2, 2020

p-ISSN 1907-1337; e-ISSN 2807-6532

Al-Ilham Kota Banjar, selalu ditanamkan oleh para aparatur sekolah yakni oleh seluruh dewan guru dan semua yang ada disekolah. Di SD Inspiratif Al-Ilham Kota Banjar ini sangat diperhatikan sekali masalah ibadah sholat berjama'ah nya, setiap guru piket senantiasa mendampingi peserta didik ketika saat jam sholat berjama'ah dimasjid, segala sesuatu nya benar-benar sangat dipantau. Dan apabila terdapat peserta didik yang tidak mengikuti shalat berjama'ah dengan alasan yang tidak jelas, maka akan mendapatkan sebuah teguran dan nasehat langsung oleh guru yang mengawasi peserta didik tersebut.

6. Melaksanakan Sholat Duha dan Qiyamullail

Dari hasil observasi, peserta didik SD Inspiratif Al-Ilham Kota Banjar, suka melaksanakan sholat duha dan qiyamullail, terlihat dari kebiasaan sebelum memulai belajar, para peserta didik wajib melaksanakan sholat duha di mesjid sekolah dan juga hampir setengahnya melaksanakan qiyamullail dirumah nya, hal itu terlihat dari buku evaluasi amalan hariannya yang setiap hari wajib di isi oleh para peserta didik.

7. Berbakti kepada orangtua, Menghormati yang Lebih tua dan menyayangi yang lebih muda

Dari hasil observasi yang peneliti lakukan, dapat dilihat bahwasanya hubungan antara peserta didik dengan rekan-rekannya nampak terlihat harmonis, rukun, tertib, dan juga disiplin. Meski terlihat jelas bahwasanya mereka peserta didik yang memiliki background latar belakang dari keluarga yang berbeda-beda adat, suku. Tetapi mereka tetap menjadi satu keluarga yang sangat erat. Para peserta didik juga menganggap tempat mereka belajar yakni di SD Inspiratif Al-Ilham Kota Banjar merupakan rumah kedua bagi mereka dilingkungan formal. Terlihat patuh dan perhatian kepada seorang pendidik, sangat nampak terlihat. Para peserta didik menganggap seorang guru itu sangat mulia, sehingga terlihat dari seluruh peserta didik yang berada di SD Inspiratif Al-Ilham Kota Banjar sangat sopan dan patuh terhadap orang yang lebih tua, terlebih kepada pendidik, wali murid, yang datang ke sekolah dan masih banyak lagi.

Meskipun terdapat beberapa dari peserta didik yang bersifat pendiam, terkesan cuek, tetapi mereka sangat menjaga kesopanan pada diri mereka dilingkungan sekolah. Tetapi masih terjadi sedikit kegaduhan oleh beberapa peserta didik didalam kelas saat seorang guru memberikan materi di dalam kelas seperti mengajak teman nya mengobrol saat ketika ada guru, sehingga hal ini dapat mengganggu teman nya yang sedang belajar, dan menjadi berisik dan akibatnya kurang fokus dalam belajar.

8. $\quad$ Saling Tolong Menolong

Dari hasil observasi yang penulis lakukan, peserta didik di SD Inspiratif Al-Ilham Kota Banjar selain ramah, dan sopan santun juga ternyata solidaritas mereka terhadap teman-temanya sangat tinggi. Hal ini terlihat dari kegiatan mereka disekolah, ketika ada temannya yang 
kesusahan maka teman lainnya membantu, ketika ada guru atau tenaga pendidik yang meminta bantuan para peserta didik tidak menolaknya, mereka sangat antusias untuk membantu orang lain.

9. Membaca dzikir setiap selesai shalat

Dari hasil observasi, terlihat sebagian besar peserta didik selalu melakukan dan membiasakan untuk berdzikir setelah selesai shalat berjama'ah disekolah dan terlihat juga pada buku evaluasi sebagian peserta didik telah membiasakan dzikir setelah selesai sholat. Meskipun masih terlihat ada beberapa peserta didik ketika selesai shalat berjama'ah ada yang mengajak teman lainya berbisik-bisik. Sehingga mengganggu kekhusukan peserta didik lainnya.

10. Menghafal al-Qur`an beserta terjemahnnya dan Hadist Nabi

Dari hasil observasi dapat disimpulkan bahwa pembiasaan perilaku baik selalu ditanamkan di sekolah ini. Dari mulai menghafal Al-Qur`an (tahfidz), lalu menghafal terjemahannya (Tarjim), dan juga seluruh peserta didik maupun tenaga pendidik wajib menghafalkan beberapa surat yang telah ditentukan oleh seorang guru dan pihak sekolah, peserta didik telah ditanamkan dan diajarkan mengenal Al-Qur`an dan menghafalkan nya, bukan hanya peserta didik saja, melainkan seluruh dewan guru juga sama harus mempunyai hafalan Al-Qur`an. Selain itu, para peserta didik juga belajar dan mengamalkan do'a- do'a harian, serta menghafalkan beberapa surat yang sudah menjadi kewajiban peserta didik dalam memenuhi salah satu syarat kenaikan kelas, dari sinilah terlihat bahwa memang benar bahwa di SD Inpiratif Al-Ilham Kota Banjar ini bukan salah satu pondok pesantren namun sekolah yang dapat menyediakan dan menghadirkan pembelajaranya seperti didalam pondok pesantren, yang menaungi pengetahuan islami serta aplikasinya dalam kehidupan sehari-hari.

\section{SIMPULAN}

Berdasarkan perumusan masalah dan pembahasan yang telah di paparkan di atas, penulis dapat memperoleh kesimpulan sebagai berikut: (1) 1. Akhlak peserta didik di SD Inspiratif Al-Ilham Kota Banjar sudah cukup baik, peserta didik sudah menunjukan prilaku sesuai indikatorindikator yang ada, tetapi ada beberapa peserta didik yang masih bertutur kata dengan nada yang keras sehingga terkesan kurang sopan. Namun mayoritas peserta didik sudah bertutur kata sopan dan santun. (2) 2.

Implementasi Bina Pribadi Islam di SD Inspiratif Al-Ilham Kota Banjar, peserta didik mendapatkan pembinaan dari guru atau murobbi melalui pembinaan dengan keteladanan, pembinaan dengan pembiasaan dan pembinaan dengan nasehat. (3) 3. Hasil Bina Pribadi Islam (BPI) dalam membina akhlak peserta didik di SD Inspiratif Al-Ilham Kota Banjar sudah cukup baik, dimana peserta didik sudah mampu melaksanakan apa yang sudah disampaikan oleh guru atau murobbinya. Bahwasanya memang terbukti didukung dengan adanya Bina Pribadi 
BESTARI

Vol. 17, No. 2, 2020

p-ISSN 1907-1337; e-ISSN 2807-6532

Islam yang sudah sangat baik, sehingga hasil dari peserta didik juga sudah cukup baik, untuk menunjang akhlak peserta didik yang mana terdapat pada indikator- indikator Bina Pribadi Islam dalam pembinaan akhlak peserta didik. Sehingga tujuan dalam membina dan memperbaiki akhlak peserta didik sudah cukup optimal.

\section{DAFTAR PUSTAKA}

Agustina, N. (2018 ). Perkembangan Peserta Didik. Yoyakarta: Deepublish.

Aisah, S. (2019). Peranan Mentor Bina Pribadi Islam Dalam Meningkatkan Kecerdasan Spiritual Siswa Kelas Viii Smp It Bina Insani Metro Tahun Pelajaran 2018/2019. Institut Agama Islam Negeri Iain Metro.

Aminah. (2017). Pendidikan Karakter Dalam Perspektif Sunnah Sebagai Upaya Peningkatan Mutu Bina Pribadi Islami Pada Peserta Didik Di Sd Islam Terpadu Fitrah Insani Langkapura. Lampung: Islam Negeri Raden Intan Lampung.

Binaria, Y. (2017). Pembinaan Akhlak Siswa Melalui Kegiatan Ekstrakurikuler Kerohanian. Universitas Islam Negeri Sunan Kalijaga Yogyakarta.

Daryanto. (2010). Kamus Bahasa Indonesia Lengkap. . Surabaya: Apollo Lestari.

Edidarmo, T. \&. (2016). Pendidikan Agama Islam Akidah Akhlak. Semarang: PT Karya Toha Putra.

Fathurrohman, M. F. (2016). Pengaruh Aktivitas Siswa Dalam Gerakan Masyarakat Maghrib Mengaji Terhadap Prestasi Belajar Mereka Pada Mata Pelajaran Pendidikan Agama Islam. . Institut Agama Islam Darussalam.

Habibah, S. (2015). Akhlak Dan Etika Dalam Islam. Jurnal Pesona Dasar, $1(4), 73-87$.

Halimah. (2017). Pelaksanaan Pembinaan Akhlak Siswa Di SDIT Nurul Iman Palembang. . Universitas Islam Negeri Raden Fatah Palembang.

Helaluddin, \&. W. (2019). Analisis data Kualitatif: Sebuah Tinjauan Teori dan Praktik. Makassar: Sekolah Tinggi Theologia Jaffray.

Irawan, M. W. (2018). Konsep Pendidik Dan Peserta Didik Menurut Abuddin Nata. . Universitas Islam Negeri Syarif Hidayatullah.

Irham. (2018). Pembinaan Akhlak Peserta Didik Melalui Kegiatan Ekstrakurikuler Di SMP Muhammadiyah 5 Kecamatan Mariso Kota Makassar. . Universitas Islam Negeri Alauddin Makassar. 
Juraini, F. H. (2018). Pembinaan Akhlak Terhadap Siswa Dalam Proses Pembelajaran Di SD Negeri Unggul Lampenerurut Aceh Besar. Jurnal Ilmiah Pendidikan Guru Sekolah Dasar, 3(2), 35-44.

Maulana, I. R. (2015). Konsep Peserta Didik Menurut Al- Ghazali Dan Implikasinya Terhadap Praktek Pendidika Di Pondok Pesantren Al-Mutawwally Desa Bojong Kecamatan Cilimus Kabupaten Kuningan. Jurnal Al Tarbwai Al Haditsah, , 1(1), 1-23.

Musianto, L. S. (2002). Perbedaan Pendekatan Kuantitatif dengan Pendekatan Kualitatif dalam Metode Penelitian. Jurnal Manajemen \& Kewirausahaan, 4(2), 123-136.

Nasution, H. A. (2019). Patologi Sosial dan Pendidikan Islam Keluarga. Surabaya: Scopindo Media Pustaka.

Pertiwi, W. H. (2015). Pemahaman Mahasiswa Atas Metode Penelitian Kualitatif: Sebuah Refleksi Artikel Hasil Penelitian. Lingua,, 10(1), 19-23.

Raco, J. R. (2010). Metode Penelitian Kualitatif Jenis, Karakteristik, dan Keunggulannya. Jakarta: Gramedia Widiasarana Indonesia.

Rahman, M. H. (2017). Implementasi Manajemen Peserta Didik Di MA Ma'arif o4 Kalirejo Lampung Tengah. . Institut Agama Islam Negeri Raden Intan Lampung.

Saehudin, I. A. (2016). Tafsir Pendidikan Konsep Pendidikan Berbasis Al-Quran. . Bandung: Perpustakaan Nasional Katalog Dalam Terbitan (KDT).

Shawmi, A. N. (2016). Analisis Pembelajaran Sains Madrasah Ibtidaiyah (MI) Dalam Kurikulum 2013. Jurnal Pendidikan dan Pembelajaran Dasar, 3(1), 121-144.

Suryadarma, Y. \&. (2015). Pendidikan Akhlak Menurut Imam Al-Ghazali Universitas Darussalam Gontor. Jurnal At-Ta'dib, 10(2), 362-381.

Sylviyanah, S. (2012). Pembinaan Akhlak Mulia Pada Sekolah Dasar (Studi Deskrptif Pada Sekolah Dasar Islam Terpadu Nur AlRahman). . Jurnal Tarbawi, 1, 191-203. 